\title{
Refugee education in countries of first asylum: Breaking open the black box of pre-resettlement experiences
}

\section{Citation}

Dryden-Peterson, S. 2015. Refugee Education in Countries of First Asylum: Breaking Open the Black Box of Pre-Resettlement Experiences. Theory and Research in Education (December 21).

\section{Published Version}

doi:10.1177/1477878515622703

\section{Permanent link}

http://nrs.harvard.edu/urn-3:HUL.InstRepos:23989485

\section{Terms of Use}

This article was downloaded from Harvard University's DASH repository, and is made available under the terms and conditions applicable to Open Access Policy Articles, as set forth at http:// nrs.harvard.edu/urn-3:HUL.InstRepos:dash.current.terms-of-use\#OAP

\section{Share Your Story}

The Harvard community has made this article openly available. Please share how this access benefits you. Submit a story.

Accessibility 


\section{Title:}

Refugee Education: Breaking Open the Black Box of Pre-Resettlement Experiences

Corresponding Author:

Sarah Dryden-Peterson

Harvard Graduate School of Education

6 Appian Way

Gutman Library 457

Cambridge, MA 02138

USA

Tel: 617-495-8162/ 617-435-2344

Email: sarah_dryden-peterson@gse.harvard.edu

\section{Biographical Note:}

Sarah Dryden-Peterson leads a research program that focuses on the connections between education and community development, specifically the role that education plays in building peaceful and participatory societies. Her research reflects connections between practice, policy, and scholarship and is strengthened through long-term collaborations with UN agencies, NGOs, and communities. Dryden-Peterson is on the faculty of the Harvard Graduate School of Education. She previously taught middle school in Boston and founded non-profits in Uganda and South Africa.

\section{Acknowledgments:}

The author wishes to thank the children, families, and other community members who have been involved in field-based research; those who contributed to data collection including Jacques Bwira, Kyohairwe Sylvia Bohibwa, Elizabeth Adelman, Michelle Bellino, Vidur Chopra, Negin Dayha, Joanna Rahman, members of the University of Nairobi/International Rescue Committee partnership, and the students of the Education in Armed Conflict class at the Harvard Graduate School of Education (2013, 2014); Amy Cheung, Pierre de Galbert, and Eleanor O’Donnell for research assistance and feedback; and Ita Sheehy, Jacqueline Strecker, and Barbara Zeus at UNHCR.

\section{Funding}

This work was supported by the Fulbright Commission, the Mellon Foundation, the Harvard Graduate School of Education, the Weatherhead Center for International Affairs at Harvard University, the United Nations High Commissioner for Refugees (UNHCR), and the International Rescue Committee (IRC). 


\title{
Refugee Education in Countries of First Asylum: \\ Breaking Open the Black Box of Pre-Resettlement Experiences
}

\begin{abstract}
The number of refugees who have fled across international borders due to conflict and persecution is at the highest level in recorded history. The vast majority of these refugees find exile in low-income countries neighboring their countries of origin. The refugee children who are resettled to North America, Europe, and Australia arrive with previous educational experiences in these countries of first asylum. This article examines these pre-resettlement educational experiences of refugee children, which to date have constituted a "black box" in their postresettlement education. Analysis is of data from the United Nations High Commissioner for Refugees (UNHCR), key informant interviews in 14 countries of first asylum, and ethnographic fieldwork and interviews in four countries. The article argues that contemporary conditions of conflict usefully inform conceptual understanding of refugee education globally, including the types of schools that refugees access in countries of first asylum and their rates of access. It further identifies three empirical themes that are common to the educational experiences of refugees in countries of first asylum: language barriers; teacher-centered pedagogy; and discrimination in school settings. The paper examines the theoretical and practical relevance of these pre-resettlement educational experiences for post-resettlement education of refugee children.
\end{abstract}

Keywords: refugees, conflict, migration, educational policies, teachers, low-income countries 


\section{Refugee Education:}

\section{Breaking Open the Black Box of Pre-Resettlement Experiences}

The number of refugees globally is at its highest level in recorded history (United Nations, 2014). In 2014 alone, 2.9 million people were newly displaced across international borders to become refugees with the onset and re-ignition of conflicts in Iraq, Mali, South Sudan, and Syria, among others (UNHCR, 2014a). These newly displaced refugees joined almost 17 million others who remained refugees from on-going and decades-old conflicts in places such as Afghanistan, Democratic Republic of Congo (DRC), and Somalia. By definition, refugees are people who have crossed an international border due to the well-founded fear of persecution. ${ }^{1}$ Currently, a total of 19.2 million people live as refugees globally; half of them are children (UNICEF, 2014; UNHCR, 2014a).

The vast majority of refugees - 86 percent - live in exile in low-income countries that neighbor their conflict-affected countries of origin (UNHCR, 2014a). Less than one percent of refugees globally access 'resettlement,' which enables permanent settlement in a more distant country, almost always a developed country (UNHCR, 2014d). Indeed, the numbers of resettled refugees are small relative to the global refugee population (see Figure 1). In 2014, the United States resettled 73,008 refugees, the largest number among countries with formal refugee resettlement programs and 67 percent of the global total of refugees resettled. By comparison, Canada resettled 10 percent, Australia 8 percent, and the remaining 15 percent were spread among the United Kingdom, Sweden, Norway, and a few other countries (UNHCR, 2014d; UNHCR, 2014c). There has been a 90 percent increase in the number of refugees resettled since 2005, and current conflicts suggest that these numbers will continue to rise (UNHCR, 2015b: 3). 
Children comprise a sizeable proportion of resettled populations. For example, 154,680 schoolaged children, aged 5 to 18, were resettled to the U.S. between 2002 and 2013 from 113 countries (Migration Policy Institute, 2014: 4-5).

Almost all refugee children arrive in North America, Europe, and Australia with previous educational experiences. Yet, this article argues, these pre-resettlement experiences of refugee children constitute a "black box" in their post-resettlement education. The existing literature on education of resettled refugee children focuses primarily on the characteristics of refugee children at the time of and after their arrival. Recently, researchers and practitioners alike have called for greater and more nuanced understanding of pre-resettlement educational experiences (Gahungu et al., 2011; Isik-Ercan, 2012; Prior and Niesz, 2013). Yet, there has been to date little attention to these pre-resettlement educational experiences of refugees, which are also often hidden from post-resettlement schools and teachers by factors such as language barriers, privacy concerns, cultural misunderstandings, and stereotypes (Bigelow, 2010; McBrien, 2011; Taylor and Sidhu, 2012). These gaps in understanding have implications for the continued educational experiences of refugee children upon resettlement.

This article examines the pre-resettlement educational experiences of refugee children with the goal of illuminating global patterns that can inform the post-resettlement education of refugee children. I focus on education of refugee children in 'countries of first asylum,' meaning the country in which they lived after fleeing from their country of origin but before arriving in a resettlement country. In the section that follows, I briefly review gaps in the current literature on the education of resettled refugee children. To address these gaps, I present a conceptual framework for understanding the pre-resettlement education of refugee children that considers contemporary conditions of conflict. I then outline the research design and the data sources of 
this study. In the findings section, I examine how refugee education is structured in countries of first asylum, rates at which refugees access education globally, and major themes in the educational experiences of refugee children in these settings, including language barriers, teacher-centered pedagogy, and discrimination in school settings. These pre-resettlement educational experiences globally bear on the continued education and academic success of refugee children who are eventually resettled in the United States, Canada, Australia, and elsewhere, and I close with a discussion of these theoretical and policy implications.

\section{Conceptual Framework: Contemporary Conflict and Refugee Education}

The educational trajectories of resettled refugee children can be divided into three periods: pre-resettlement, at arrival, and post-resettlement. Research has focused on the two latter periods, with scant attention to the educational experiences of refugees prior to their resettlement.

Well-documented are, firstly, the educational attainment, literacy, and English proficiency of refugees at the time of their arrival in a resettlement country and, secondly, language learning and processes of integration in post-resettlement schools. A full review of this literature is beyond the scope of this paper. Important to this analysis, is that we know refugee children arrive to resettlement countries with limited English proficiency, and they need support to learn English, or other resettlement country language of instruction in the cases of Sweden and Norway, for example (Brown et al., 2006; Fennelly and Palasz, 2003; McBrien, 2005; NykielHerbert, 2010; Prior and Niesz, 2013; Walker-Dalhouse and Dalhouse, 2009). They are also embedded in families with low literacy rates and educational attainment. For example, upon arrival in the U.S., 23 percent of refugee men and 27 percent of refugee women over the age of 
25 have not completed high school, lower than rates among the U.S.-born population (Migration Policy Institute, 2014: 17). We also know that refugee children experience challenges related to social integration in school settings (Bigelow, 2010; Buck and Silver, 2012; Due and Riggs, 2009; Taylor and Sidhu, 2012; Rutter, 2003; Dippo et al., 2012; Rutter, 2006; Arnot and Pinson, 2005; Isik-Ercan, 2012) and on-going challenges related to trauma exposure (Betancourt et al., 2012; Gahungu et al., 2011; Schweitzer et al., 2006; Szente et al., 2006).

Post-resettlement trajectories and the relevant educational characteristics of refugee children and their parents upon arrival are critical dimensions of the education of resettled refugee children. Underexplored are the pre-resettlement experiences that inform the arrival and post-resettlement periods. Yet knowing where, for example, a refugee child falls on a spectrum of English proficiency on the day she arrives in the United States is different than understanding the experiences that led her to that place. A black box remains related to these pre-resettlement educational experiences of refugee children.

\section{Contemporary Conditions of Conflict}

Contemporary conditions of conflict shape the pre-resettlement experiences of refugee children. The nature of conflict has changed since the end of the Cold War, and three dimensions of it are particularly salient for eventual education in resettlement. First, contemporary conflicts are more deadly for civilians, especially for children, and more destructive of civilian infrastructure, including schools (UNICEF, 2008; Save the Children, 2013). In 2014, 679 children were killed or severely injured in Iraq, including through execution; 561 were killed and 4,271 injured in Gaza (United Nations, 2015: 15, 19); in Syria, there were 35 military and paramilitary attacks on schools, which killed 105 children and injured over 300; in South Sudan 
alone, 12,000 children were recruited as child soldiers (UNICEF, 2014). Current forms of conflict mean that children, being at particular risk, are more likely to become refugees.

Second, conflicts are increasingly protracted. While most refugees flee their countries of origin with the intention of returning home rapidly, the average duration of exile for refugees is 17 years (Internal Displacement Monitoring Centre, 2014). Many recent conflicts have lasted for decades, and are on-going, such as in Afghanistan (33 years), DRC (19 years), and Somalia (23 years) (Center for Systemic Peace, 2013). For refugee children, the protracted nature of conflict and exile can often results in disrupted education as more the norm than the exception. It also increased the likelihood of educational experiences outside of the national education system of a country of origin.

Third, and related, refugees who will eventually be resettled usually experience extended periods of exile before that resettlement. At present, almost all refugees are resettled from countries of first asylum such as (in order of number of resettlement submissions) Turkey, Malaysia, Lebanon, Jordan, Kenya, Nepal, and Thailand rather than from their countries of origin - Syria, Myanmar, Iraq, and Somalia. More specifically, for example, few Somali refugees arrive in the United States directly from Somalia; they are resettled to the U.S. after years (often decades) of living in exile in refugee camps. Nearly half of the Somali refugees resettled to the United States between 2002 and 2013 had lived in Kakuma refugee camp in Kenya (Migration Policy Institute, 2014: 14), just one of more than ten major Somali-hosting refugee camps in East Africa.

This initial exile in a country of first asylum is unlike typical experiences for previous large groups of resettled refugees, such as Vietnamese, Soviets, and Cubans resettled to the U.S. in the 1970s and 1980s. The conditions of these resettlements were unique, but they shared the 
characteristics of direct arrival in the U.S. from countries of origin. For example, Vietnamese refugees arrived in the United States in the 1970s and 1980s primarily through the U.S.sponsored evacuation and UNHCR’s Orderly Departure Program. This does not mean that Vietnamese refugees did not live in camps; however, those Vietnamese refugees who lived in camps were much less likely to be resettled to the United States, and those who were resettled from camps lived there for very short periods of time (UNHCR, 2000: 90; Robinson, 1998: 127159).

\section{Refugee Education in a Global Context}

The 1951 Convention relating to the Status of Refugees and its companion 1967 Protocol provide international norms defining who is a refugee, refugee rights, and the legal obligations of the state. Article 22 of the 1951 Convention specifies the right to education for all children, including refugees. According to the Convention, signatory states "shall accord to refugees the same treatment as is accorded to nationals with respect to elementary education... [and] treatment as favourable as possible... with respect to education other than elementary education” (UNHCR, 2010).

The United Nations High Commissioner for Refugees (UNHCR) is the organization mandated with the physical, political, and social protection of refugees; with the delivery of humanitarian assistance such as food, shelter, and water; and also with the provision of education. The UNHCR Education Strategy, 2012-2016 guides this provision of education. This Strategy focuses on expanding access to education at primary and secondary levels (UNHCR, 2012: 10-13, 18-23); augmenting the quality of education for refugees, particularly through teacher training (UNHCR, 2012: 11-13); ensuring that schools are safe learning environments for 
refugee children (UNHCR, 2012: 14-17); and integrating refugee children into national education systems wherever possible (UNHCR, 2012: 8, 31-33).

As a constituent body, UNHCR's work on education, as on other issues, is coordinated with the governments of countries in which refugees reside. Refugee education thus depends on the laws, policies, and practices in place in each national context. Importantly, the countries of first asylum where 86 percent of the world's refugees live are generally characterized by already over-stretched education systems and often fragile political and economic institutions (UNHCR, 2014e: 2).

\section{Research Design and Data Sources}

This article draws on three unique datasets: UNHCR data on refugee access to education; key informant interviews; and ethnographic field-based case studies. The UNHCR data on access to education for refugees describe the largest refugee populations globally and represent 14 countries of first asylum: Bangladesh, Chad, Egypt, Ethiopia, Iran, Kenya, Lebanon, Malaysia, Pakistan, Rwanda, South Sudan, Sudan, Uganda, and Yemen (see Figure 1). These are the countries to which refugees flee from their countries of origin and in which they access education as refugees. Refugee populations from a single country of origin are often spread over multiple countries of first asylum. For example, among the these 14 countries, large populations of Somali refugees live in Ethiopia, Kenya, Uganda, and Yemen; Afghan refugees live in Iran, Malaysia, and Pakistan; Syrian refugees in Egypt and Lebanon. Despite their large numbers, Palestinian refugees are not included in this analysis, as education operations for Palestinians are notably different than for all other refugees globally and under the mandate not of UNHCR but of the United Nations Relief and Works Agency for Palestinian Refugees (UNRWA) (UNRWA, 
2011; Universalia Management Group, 2010).

In all cases, the most recent UNHCR data are presented, which is 2014 unless otherwise noted. These data draw from both publically available data (through Global Focus, http://reporting.unhcr.org) and restricted data from the internal performance measurement system and country-level Operations Reports, accessed through a long-standing research relationship with UNHCR.

There are two central challenges related to available data on refugee education, both of which lead to overly optimistic estimates of refugee enrollment in school. First, for national children, it is possible to calculate net enrollment ratios (NER), which are the enrollment of the official age group for a given level of education, expressed as a percentage of the population in that age group. For refugees, however, data on age is often not available. As a result, data only allows for the calculation of gross enrollment ratios (GER), which are the total enrollment in a specific level of education, regardless of age, expressed as a percentage of the population in the official age group corresponding to that level of education. GERs overestimate enrollment, especially when overage children are present at a given grade level, due to late entry into school, missed schooling, or repetition, all common scenarios among refugee children. Second, available data are far more complete for refugees who are registered with UNHCR, which happens as a pre-requisite to receiving legal protection and/or assistance, and yet assisted refugees do not represent all refugees, especially in urban areas. Refugees who are registered are more likely to be enrolled in school and estimates miss out-of-school children who are not counted as part of any national or refugee data collection. For these reasons, even the low estimates of school enrollment for refugees are likely optimistic and should be read as such.

Semi-structured interviews were conducted with key informants working in these 14 
countries ( $\mathrm{n}=80)$, including UNHCR staff and partners, such as Ministry of Education officials, NGO staff, and other UN agency staff. These interviews were conducted between March 2013 and April 2014, facilitated through a research partnership with UNHCR and the author's university. These interviews were designed to elicit understanding of specific dimensions of refugee education in each country context, including the relevance of the UNHCR Education Strategy 2012-2016 and the challenges to its implementation.

This article also draws on data from ethnographic field-based case studies conducted between 2002 and 2014. These case studies were conducted in four countries of first asylum (Uganda, Kenya, Malaysia, and Egypt) with refugee children from four specific conflict-affected countries of origin (Democratic Republic of Congo, Somalia, Myanmar, and Syria, respectively). These case studies included in-depth, semi-structured interviews with children ( $\mathrm{n}=285)$, parents $(n=116)$, teachers $(n=116)$, and key informants $(n=86)$ such as UNHCR staff members, national Ministry of Education staff members, NGO staff members, and refugee community leaders. They also included structured classroom observations ( $n=203)$ and extended participant observation (see Table 1). While the form of data collection was not identical across sites, the data are comparable in their context-specific approaches to understanding the educational experiences of refugee children in countries of first asylum.

In any country of first asylum, refugees may live in refugee camps, locally settled amid national populations in rural areas, or they may live in urban areas, with the context of their residence depending on local policies, practices, and individual refugees' choices. The data that form the basis of this analysis were collected in the sites relevant to the particular country context. For example, in Egypt and Malaysia, there are no refugee camps and data were collected in urban areas; in Kenya and Uganda, refugees reside in camps and in urban areas, and so data 
were collected in both contexts. In this way, the data in this article represent the experiences of refugees in refugee camp and urban settings; they do not represent the experiences of refugees self-settled amid local populations in rural areas who, by nature of having little to no contact with UNHCR, are not frequently resettled.

\section{Findings}

This section presents and interprets the findings in three parts. First, I examine the structures that influence the ways that refugees access education globally and identify resulting types of schools. Second, I analyze rates of access to education in 14 countries of first asylum. Finally, I explore the educational experiences of refugee children globally, identifying themes that have particular relevance for their post-resettlement education.

\section{Structures of Refugee Education Globally}

Expansion of access to education for refugees has paralleled global progress toward universal primary education. As early as the 1990 Jomtien World Declaration on Education for All, “war, occupation, [and] civil strife” were identified as some of the "daunting problems” that “constrain efforts to meet basic learning needs” (World Conference on Education for All, 1990).

UNHCR data and interviews with key informants across countries indicate that there are three primary structures through which refugees access education globally: in separate, refugeeonly schools in refugee camps; in national schools, primarily in urban areas of countries of first asylum; and in informal schools, in camps or urban areas, initiated by refugee communities. These structures reflect contemporary conditions of conflict and the ways in which international assistance is delivered. 
From the 1980s through the 2000s, refugee camps were the favored model of delivering aid to refugee populations by UNHCR, for reasons of efficiency, and by countries of first asylum, for reasons of security (UNHCR, 2000; Verdirame and Harrell-Bond, 2005). This was the era of large refugee camps for Vietnamese and Cambodians on the Thai border, Rwandans in eastern DRC, and Afghans in Pakistan (Verdirame and Harrell-Bond, 2005; Harrell-Bond, 1986). The institutionalization of refugee camps led to the structural necessity of refugee children attending separate schools rather than schools connected to national education systems. Refugee education at this time was also characterized as a short-term endeavor as the size of refugee populations made countries of first asylum reluctant to consider their permanence. UNHCR policy reflected these realities in the form of aligning education as closely as possible to the country of origin, specifically in terms of curriculum and language, to facilitate swift return of refugees to their countries of origin (UNHCR, 2003).

Current UNHCR policy de-emphasizes refugee camps and instead focuses on pursuing “alternatives to camps," in order to remove the "limitation on the rights and freedoms of refugees” inherent in a camp structure (UNHCR, 2014f: 4). Nevertheless, 40 percent of refugees globally continue to live in refugee camps, and they remain an important site of access to education for refugees globally.

More than half of refugees now live in cities (UNHCR, 2009: 2; UNHCR, 2014f), however, and, in these settings, refugee children live amid national populations with national schools as the only viable option for education. Current UNHCR policy thus focuses on “integration of refugee learners within national systems” (UNHCR, 2012: 8). Interviews with UNHCR staff and other key informants demonstrate that the adoption of this approach was not only a result of increased urban populations, but also reflected the protracted nature of conflict 
and beliefs that education within a national system of teacher training and certification of learning would be of higher quality.

The integration of refugees within national systems emerged gradually, responding to these conditions, but was only formalized in UNHCR policy in 2012. Ethnographic fieldwork and interviews in Kenya reveals, for example, that Somali refugees arriving in Kenya beginning in the early 1990s followed the Kenyan curriculum and yet refugee camp schools were only formally registered to become national Kenyan government schools in 2014. In camps settings, 'integration' has come to mean the use of the curriculum and language of the country of first asylum even though school spaces may be segregated in that they do not bring together refugee and national children. In urban areas, 'integration' usually means use of the national curriculum and language as well as physically being together in school with nationals of the country of first asylum. Analysis of UNHCR data reveal that 5 out of 14 priority countries integrated refugees to the national curriculum and language in 2010; by 2014, 11 of 14 countries did so.

Informal schools, initiated by refugee communities, are also an important site of access to education for refugees. This is particularly true in countries of first asylum where refugee rights are limited. In Uganda, for example, refugees did not have the legal right to reside in urban areas until 2006. Ethnographic fieldwork in Kampala documents that, prior to that time, the only education available to refugee children in urban areas was in refugee-initiated and supported schools that operated outside of any formal assistance from UNHCR or NGOs. Malaysia and Bangladesh have not ratified the 1951 Convention and thus do not guarantee the right to education for refugees; in these settings, governments do not permit refugees to access national schools. Interviews and observations indicate that relationships between UNHCR and 
government are tenuous vis-à-vis supporting educational opportunities, with informal schooling the only possibility.

The establishment of informal schools can also reflect the kind of education refugee parents seek for their children. In many countries of first asylum, Muslim refugee communities create duksis, or Koranic schools, to complement formal education; more formal madrassas also operate in many refugee settings, providing instruction in Arabic, mathematics, and history and sometimes other subjects (UNHCR, 2013; Gerstner, 2009: 185). Community-initiated schools may substitute for available formal education, as observed in Dadaab refugee camp in Kenya, where refugee parents chose to create their own primary schools where they could ensure smaller class sizes and control over curriculum (see also UNHCR and CARE, 2009).

In addition, sites of access to education for refugees in countries of first asylum reflect regional conflict dynamics. Egypt, for example, has ratified the 1951 Convention, but with the exception of Article 22, the right to education. Until recently, the population of refugees in Egypt was largely of sub-Saharan African origin, and access to education was limited to informal, often clandestine, schools (Grabska, 2006). The influx of Syrian refugees to Egypt, beginning in 2011, resulted in a shift in policy, allowing Syrians to access Egyptian national schools, but continuing to bar Somalis, Ethiopians, and Eritreans from public schools (UNHCR, 2014b). Interviews reveal the acceptance of Syrian refugees in public schools to be part of a commitment to refugees of Arab origin.

\section{Access to Education for Refugees}

Access to education for refugees is uneven across countries of first asylum. The most recent UNHCR data suggest that, in 2014, 50 percent of refugees had access to primary school. 
This access rate compares to 93 percent of all children globally (UNESCO, 2015: 6). At the secondary level, 25 percent of refugees had access to education in 2014 whereas 62 percent did globally (UNESCO, 2015: 10). ${ }^{2}$

Within these global rates, analysis of UNHCR enrollment data indicates wide variation in access to education across countries of first asylum (see Table 2). For example, at the primary level, only 37 percent of refugee children access education in Lebanon. Low enrollments persist in countries with protracted populations as well, such as in Pakistan where Afghans represent the largest protracted population globally (UNHCR, 2015a), and where only 43 percent of children access primary education. In some countries of first asylum, access rates are higher, such as in Bangladesh, Egypt, Iran, South Sudan, and Yemen, where more than 80 percent of refugees access primary education.

Secondary rates of access for refugees are lower than primary access rates across countries of first asylum. They also vary widely. Egypt and Yemen have rates at 81 and 80 percent, respectively. In most countries of first asylum, however, secondary education is open to very few refugees. In Kenya and Pakistan, for example, which represent two of the largest and most protracted refugee populations in the world, only 4 percent and 5 percent of refugees respectively access secondary school.

Refugees usually access primary and secondary school in countries of first asylum at lower rates than do nationals in the same countries. These differences are often stark, particularly in countries that have achieved near universal access for nationals. For example, while 97 percent of nationals access primary education in Malaysia, only 47 percent of refugees do, and while 91 percent of nationals in Uganda access primary education, only 66 percent of refugees do. In a few cases, South Sudan, Sudan, and Yemen, refugees access education at higher rates 
than nationals; in these cases, national education systems are severely disrupted due to conflict and national rates are subsequently very low.

Variation in access rates reflects multiple ways in which education is disrupted for refugee children. Ethnographic data from Uganda, Kenya, Malaysia, and Egypt indicate the salience of acute conflict, which makes routes to school dangerous, destroys school infrastructure, and renders education systems non-functional; legal restrictions whereby a country of first asylum restricts refugee children from entering national schools and/or UNHCR from providing education; and on-going migration to escape renewed conflicts or to pursue livelihood opportunities.

In Kuala Lumpur, the capital of Malaysia, for example, refugee children described being hesitant to go to school. Despite the 73 community-based schools registered with UNHCR, refugee children faced the dangers of exposure to the authorities given a lack of legal status and the distances they needed to walk to get to school. In interviews, parents described the risks of arrest by police and abuse by citizens. They said that at moments when tensions between refugees and the authorities were particularly high, refugee families elected to keep their children home from school.

The experiences of Amaziah, a pseudonym, a refugee living in Uganda, further illustrate the effects of school disruptions for refugee children. I interviewed Amaziah and his family three times between 2002 and 2005 and observed classes in his school in each of these years. Amaziah did not begin his education at the appropriate age, as militias occupied schools in his home area of eastern Democratic Republic of Congo (DRC). When his family fled to Uganda, they decided to live in Kampala, the country's capital, at a time when it was not legal for refugees to do so. However, they had lived in a city in DRC, and his father, an artisan, could pursue his livelihood 
in Kampala. The family's longer-term vision was resettlement to the United States, but they were only eligible for resettlement if they established residence in a refugee camp. The dual goals of pursuing a current livelihood and future resettlement were at odds. Amaziah thus moved continuously between the city and the refugee camp. Each time the family received word that UNHCR was conducting a population census in the camp, they boarded up their house in Kampala and travelled back to the camp to take up residence there. One year, this back and forth movement resulted in Amaziah missing his final exams and needing to repeat the entire year of school.

\section{Educational Experiences of Refugee Children}

From analysis of classroom observation data and interview data from teachers and refugee children emerge themes of the educational experiences of refugees in countries of first asylum that are particularly relevant for their post-resettlement education: language barriers; teacher-centered pedagogy; and discrimination in school settings. Below, I explore the global patterns for each of these themes, providing select country-specific examples. While only brief examples are provided here, they were chosen to be representative of the overall ethnographic dataset and corroborated by interviews in the 14 countries hosting the largest number of refugees globally.

\section{$\underline{\text { Language Barriers }}$}

Refugee children spend a disproportionate amount of time learning languages while often falling behind in age-appropriate academic content. Most refugee children transition to a new language of instruction in a country of first asylum. For example, refugees from Somalia 
transition from Somali to English in exile in Kenya and Uganda; refugees from DRC transition from French to English in Uganda and Rwanda; and refugees from Sudan transition from Arabic to French in Chad. Interviews and observations make clear that a common strategy for language learning in this context of language transition is to place refugees in classes with younger children. For example, Annette, a pseudonym, whom I interviewed in a refugee camp in southwest Uganda three times between 2002 and 2005, had been in high school in DRC before she fled to Uganda. Coming from a French language education system in DRC, Annette was placed in the equivalent of second grade in Uganda, which was an English language education system. Classroom observations revealed that this practice was the norm; about one third of the children in Annette’s primary school class were severely overage, their long teenage bodies folded up to sit on the floor with seven and eight year olds.

On-going migration and shifting policies also contribute to the ways in which language learning shapes the educational trajectories of refugee children pre-resettlement. Henri, a pseudonym, whom my research team interviewed in Burundi in 2013 when he was a university student, exemplifies a typical pathway through language. Throughout his childhood, Henri lived as a refugee in exile in Tanzania. In primary school, he followed the Tanzanian curriculum in English and Swahili; he began secondary school following the Burundian curriculum officially in French and Kirundi, but since there were only Tanzanian teachers, the languages used remained mostly English and Kiswahili; and then, when his refugee camp was closed, he relocated to a new refugee camp to complete secondary school following the Congolese curriculum in French. Upon arrival in a resettlement country, refugee children like Annette and Henri may have fallen years behind in content mastery not related to their abilities but due to continual shifting of language of instruction and the resulting lack of exposure to subject-matter content. 


\section{Teacher-Centered Pedagogy}

Refugee education in countries of first asylum is characterized by teacher-centered pedagogy, with lectures a central feature and heavy reliance on factual questions. This pedagogical style persists in refugee education, and more broadly across low- and middleincome countries (Tao, 2013; Vavrus and Bartlett, 2013), despite policies that place a high value on child-centered, participatory teaching methods (Global Education Cluster, 2010; INEE, 2010). Classroom observations in schools serving Somali and Sudanese refugees in Nairobi and Kakuma refugee camp in Kenya demonstrate the centrality of lecture as a pedagogical method. Our research team found that lectures were central in 46 of 53 classroom observations conducted in 2013. These lectures were characterized primarily by teachers' didactic presentations. Children's participation was limited to factual questions posed by the teacher that required children to repeat only what the teacher had just said. For example, in an informal school in Nairobi, a teacher asked his almost exclusively Sudanese students: "What do we call [it] when you grow flowers only?”, to which the class chorused back, "floriculture,” mentioned orally and written on the board only moments before. In a classroom in a Kenyan public school serving mostly Somali students, the teacher asked "who can tell me? We have two forms of trade, which ones are they?" The only accepted answers were “domestic” and “international,” again cited in the lecture and written on the board earlier in the same lesson.

In only 17 of the 53 lessons we observed did children ask any questions at all, and in only 6 was more than one question posed during the entire lesson. These questions, like the ones posed by teachers, were primarily factual or definitional in nature. Classroom observations across the dataset indicate that in their pre-resettlement education, refugee children often have no 
experience with child-centered activities or with expectations for working in groups, asking questions, or engaging in exploration. In resettlement countries, teachers may assume that silence, failure to ask questions, and difficulty in self-directed exploration means refugee children have few contributions to make in class. Instead, refugee children may be following what they understand from their pre-resettlement education to be proper classroom conduct.

\section{Discrimination in School Settings}

Refugee children often experience discrimination in their pre-resettlement education. Assumed in much of the literature is that refugee children experience the process of cultural adaptation and marginalization vis-à-vis schools and teachers for the first time when they arrive in a resettlement country. For most refugees, however, these experiences are not usually new: by definition, they fled their homes due to persecution, and most also previously entered a new education system in a country of first asylum. Ethnographic observations and interviews with children reveal frequent experiences of discrimination, primarily in the content of the curriculum and in treatment by peers and teachers.

The instructional content to which refugee children are exposed in countries of first asylum can be at best difficult to relate with and at worst highly politicized and discriminatory. For example, ongoing violence in Kenya attributed to Al-Shabaab, a militant group based in Somalia, has fostered a hostile environment for Somali refugee children in Kenyan schools, where the discourse has at times been reduced to, "refugees equal terrorists.” At the end of one class in Nairobi, observed in 2013, the Kenyan teacher said to the mostly refugee children: "Do we fight?” “No!” the children exclaimed in response. “Do we call each other refugee?” he said “No!” they chanted again. "Refugee” was a bad word. 
Similarly, in Egypt, refugee parents described bullying among children in school settings, which increased in intensity in relation to the overall climate of fear for Syrians in Egypt. After the overthrow of Egypt's short-lived Muslim Brotherhood government by a military coup, the Egyptian media adopted a stronger public position against the opposition in Syria related to the opposition’s perceived links with the Syrian Muslim Brotherhood. Refugee children felt the impact of this change in public perception in schools. Syrian parents, in 2014, described how their children were faced with aggressive questions about "why they quit Syria, why they were in Egypt...why [they] did not go back to their own country.” These pre-resettlement experiences of discrimination in school settings have the potential to make refugee children and their parents wary of schools and teachers in resettlement countries. These previous experiences may also compound additional discrimination refugee children face in resettlement schools, including expectations of how discrimination is addressed - or not addressed - by teachers and parents.

\section{Education of Refugees in Resettlement: Continuation of a Global Trajectory}

Through processes of exile in countries of first asylum and resettlement to the United States, refugees must leave behind many aspects of their lives: material goods, in-person social networks, and usually any clear sense of what the future holds for them and for their children. Many refugees express the idea that education is the one thing that cannot be left behind (Dryden-Peterson, 2011; Winthrop and Kirk, 2011). Yet pre-resettlement educational experiences of refugee children remain largely opaque to post-resettlement researchers and teachers. Whether or not these experiences are made visible or understood post-resettlement, they do remain part of the educational trajectories of refugee children. Refugee children do not leave them behind. 
This article begins to build conceptual and empirical understandings of pre-resettlement educational experiences of refugee children who are resettled to countries such as the U.S., Canada, Australia, the U.K, and others. Conceptually, the analysis emphasizes the relevance of conflict conditions to the structures of refugee education and the types of educational experiences refugee children have pre-resettlement. It also highlights that, rather than starting anew upon arrival in the United States, most contemporary refugee children have experienced education in countries of first asylum, which are in most cases low-income countries. While the education of refugee children in resettlement takes place locally, it is also the continuation of global trajectories.

This article points to three themes that emerge as common to these global trajectories of refugee education: language barriers; teacher-centered pedagogy; and discrimination in school settings. Equipped with knowledge of these general experiences, teachers in resettlement schools stand to be better able, for example, to identify educational needs based on prior exposure to academic content and language as opposed to innate capacities for learning; to explicitly teach skills for the kind of participation expected in classrooms; and to openly discuss issues of discrimination in schools toward the development of trusting relationships. Bringing students' personal histories - educational and otherwise - into the classroom is, of course, not a new line of thinking. It speaks to a "funds of knowledge" approach in which teachers are also learners about the cultural and cognitive resources of their students' families and can incorporate these assets into the classroom (Moll et al., 1992).

These three themes do not encompass the totality of refugee children's pre-resettlement educational experience and do not take the place of understanding the unique experiences of each child. The themes do, however, help to define the kinds of questions to ask about pre- 
resettlement education. These questions can help to push forward the work of teachers as they continue to open the black box of global pre-resettlement educational experiences of resettled refugee children.

\section{Notes}

\footnotetext{
${ }^{1}$ In this article, the term "refugee" describes any person with recognized refugee status in a country of asylum. Refugee status may be granted prima facie, meaning that it is applied at the group level to all refugees from a particular county (e.g., to all Congolese who flee to Uganda), or through an individual Refugee Status Determination (RSD) process.

${ }^{2}$ Data on refugee enrollments reflect 2014. Global enrollment rates, however, are not available for 2014 and reflect the most recent data reported in the UNESCO Global Monitoring Report and the World Bank Data Bank. In most cases, global data reflects 2012, but in some cases data is only available for earlier years. In most countries not affected by conflict, access to education has increased at both primary and secondary levels over time (UNESCO, 2015); for the purposes of these comparisons, therefore, we can assume that the numbers presented here represent an underestimate of the gap between refugee and national enrollments.
}

\section{Acknowledgements}

[Removed for peer review.]

\section{Funding}

This work was supported by [removed for peer review]. 
Figure 1. Global Distribution of Refugees in Countries of First Asylum and Countries of Resettlement, December 2014

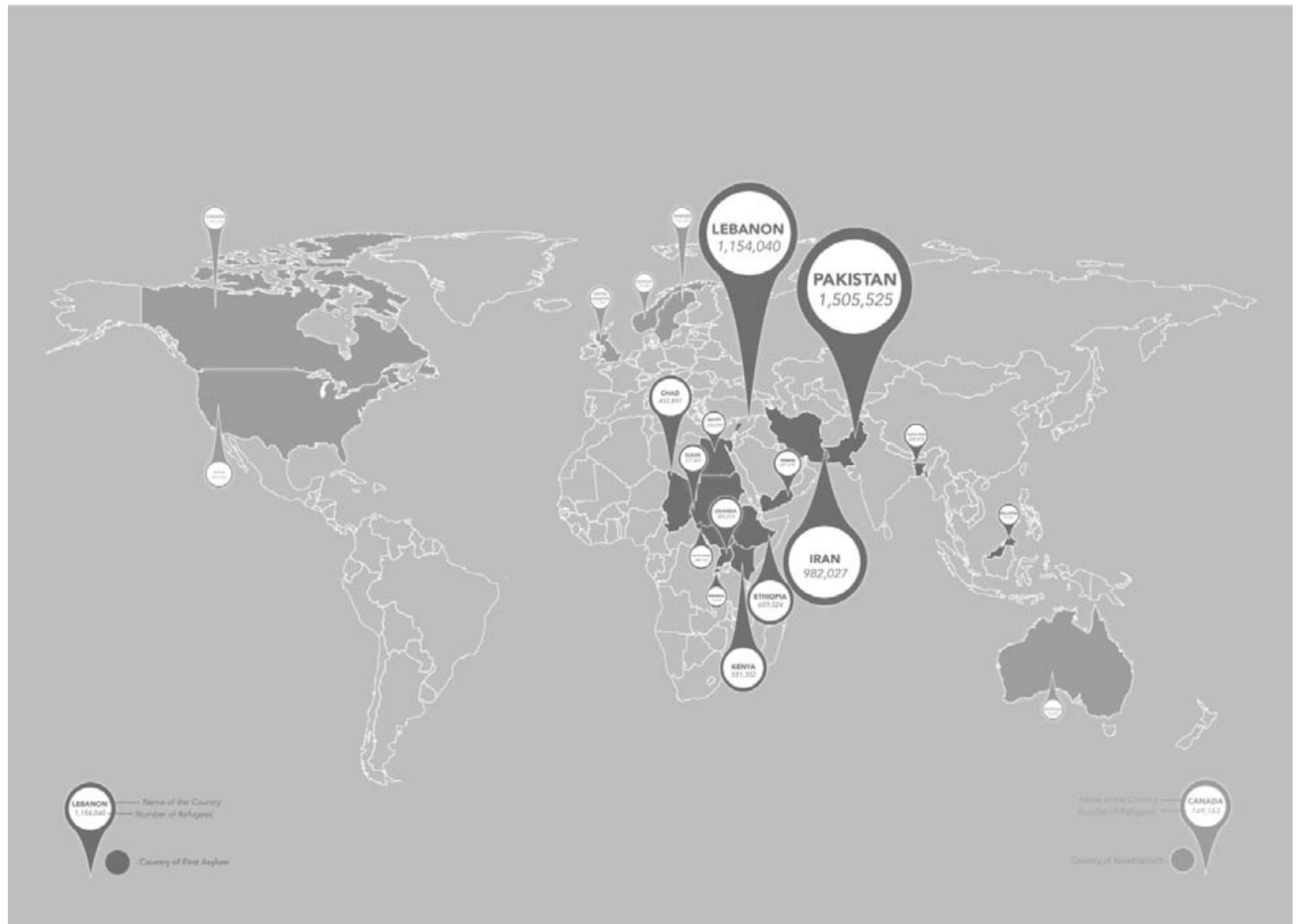

Data source: UNHCR 
Table 1. Data Sources for Ethnographic Case Studies: Four Refugee Populations in Four Countries of FirstAsylum, 2002-2014

\begin{tabular}{|c|c|c|c|c|c|c|c|}
\hline $\begin{array}{c}\text { Country of } \\
\text { origin }\end{array}$ & $\begin{array}{c}\text { Country of } \\
\text { first asylum* }\end{array}$ & Teachers & Children & $\begin{array}{l}\text { erviews } \\
\text { Families }\end{array}$ & Key informants & $\begin{array}{c}\text { Classroom } \\
\text { observation }\end{array}$ & $\begin{array}{l}\text { Participant } \\
\text { observation }\end{array}$ \\
\hline DRC & Uganda & 45 & 168 & 106 & 30 & 135 & 18 weeks \\
\hline Somalia & Kenya & 64 & 112 & - & 22 & 68 & 3 weeks \\
\hline $\begin{array}{l}\text { Myanmar } \\
\text { (Rohingya) }\end{array}$ & Malaysia & - & 5 & 5 & 11 & - & 12 weeks \\
\hline Syria & Egypt & 7 & - & 5 & 23 & - & 2 weeks \\
\hline
\end{tabular}

* sites of data collection

Source: Author’s Fieldwork, 2002-2014. 
Table 2. Enrollment Ratios for Refugee and National Children in Primary and Secondary Schools in 14 Countries of First Asylum

\begin{tabular}{l|cc|cc}
\hline $\begin{array}{l}\text { Country of First } \\
\text { Asylum }\end{array}$ & $\begin{array}{c}\text { Refugee } \\
\text { Primary } \\
\text { Enrollment } \\
\text { Rate (2014) }\end{array}$ & $\begin{array}{c}\text { National } \\
\text { Primary } \\
\text { NER }\end{array}$ & $\begin{array}{c}\text { Refugee } \\
\text { Secondary } \\
\text { Enrollment } \\
\text { Rate (2014) }\end{array}$ & $\begin{array}{c}\text { National } \\
\text { Secondary } \\
\text { NER }\end{array}$ \\
\hline Bangladesh & $84 \%$ & $92 \%^{4}$ & $10 \%$ & $48 \%^{2}$ \\
Chad & $55 \%$ & $86 \%^{1}$ & $11 \%$ & $11 \%^{7}$ \\
Egypt & $80 \%$ & $95 \%^{3}$ & $81 \%$ & $85 \%^{1}$ \\
Ethiopia & $56 \%$ & $65 \%^{5}$ & $23 \%$ & $26 \%^{5,8}$ \\
Kenya & $65 \%$ & $84 \%^{2}$ & $5 \%$ & $5 \%^{2}$ \\
Iran & $80 \%$ & $98 \%^{1}$ & $72 \%$ & $82 \%^{2}$ \\
Lebanon & $37 \%$ & $93 \%^{1}$ & $19 \%$ & $68 \%^{2}$ \\
Malaysia & $47 \%$ & $97 \%^{6}$ & $18 \%$ & $69 \%^{2}$ \\
Pakistan & $43 \%$ & $72 \%^{1}$ & $5 \%$ & $38 \%^{1}$ \\
Rwanda & $75 \%$ & $93 \%^{1}$ & $58 \%$ & $14 \%^{3,8}$ \\
South Sudan & $82 \%$ & $41 \%^{3}$ & $61 \%$ & $2 \% \%^{3,8}$ \\
Sudan & $58 \%$ & $54 \%^{2}$ & $18 \%$ & n.d. \\
Uganda & $66 \%$ & $91 \%^{1}$ & $20 \%$ & $22 \%^{4}$ \\
Yemen & $83 \%$ & $80 \%$ & $42 \%^{2}$ \\
\hline
\end{tabular}

${ }^{1} 2013,{ }^{2} 2012,{ }^{3} 2011,{ }^{4} 2010,{ }^{5} 2006,{ }^{6} 2005,{ }^{7} 2003,{ }^{8}$ lower-secondary school only

Source: All refugee data from UNHCR; all national data from World Bank Data Bank 


\section{References}

Arnot M and Pinson H. (2005) The education of asylum-seeker and refugee children: A study of LEA and school values, policies and practices. Cambridge: Faculty of Education, University of Cambridge.

Betancourt TS, Newnham EA, Layne CM, et al. (2012) Trauma History and Psychopathology inWar-Affected Refugee Children Referred for Trauma-Related Mental Health Services in the United States. Journal of Traumatic Stress 25: 682-690.

Bigelow M. (2010) Mogadishu on the Mississippi : language, racialized identity, and education in a new land, Chichester, West Sussex, U.K. ; Malden, MA: Wiley-Blackwell.

Brown J, Miller J and Mitchell J. (2006) Interrupted schooling and the acquisition of literacy: Experiences of Sudanese refugees in Victorian secondary schools. Australian Journal of Language \& Literacy 29: 150-162.

Buck P and Silver R. (2012) Educated for change? : Muslim refugee women in the west, Charlotte, N.C.: Information Age Pub.

Center for Systemic Peace. (2013) Global Conflict Trends. Available at: http://www.systemicpeace.org/conflict.htm.

Dippo D, Basu R and Duran M. (2012) Settlement and Schooling: Unique Circumstances of Refugees and Forced Migrants in Post-War Toronto Suburbs. Canadian Ethnic Studies 44: 45-57.

Dryden-Peterson S. (2011) Refugee Education: A Global Review. Geneva: UNHCR.

Due C and Riggs D. (2009) Moving Beyond English as a Requirement to "Fit In": Considering Refugee and Migrant Education in South Australia. Refuge 26: 55-64.

Fennelly K and Palasz N. (2003) English Language Proficiency of Immigrants and Refugees in the Twin Cities Metropolitan Area. International Migration 41: 93-125.

Gahungu A, Gahungu O and Luseno F. (2011) Educating culturally displaced students with truncated formal education (CDS-TFE): The case of refugee students and challenges for administration, teachers, and counselors. International Journal of Educational Leadership Preparation 6.

Gerstner E. (2009) Hope for the future: issues of educational certitication in Dadaab, Kenya. In: Kirk J (ed) Certification counts: recognizing the learning attainments of displaced and refugee students. Paris: UNESCO-IIEP, 183-191.

Global Education Cluster. (2010) The Joint Education Needs Assessment Toolkit. Geneva: Education Cluster Unit.

Grabska K. (2006) Marginalization in Urban Spaces of the Global South: Urban Refugees in Cairo. Journal of Refugee Studies 19: 287-307.

Harrell-Bond BE. (1986) Imposing aid : emergency assistance to refugees, Oxford [Oxfordshire] ; New York: Oxford University Press.

INEE. (2010) Minimum Standards for Education: Preparedness, Response, Recovery. New York: INEE.

Internal Displacement Monitoring Centre. (2014) Global Estimates 2014: People displaced by disasters. Geneva: Internal Displacement Monitoring Centre.

Isik-Ercan Z. (2012) In pursuit of a new perspective in the education of children of the refugees: Advocacy for the "family". Educational Sciences: Theory and Practice 12: 3025-3038.

McBrien JL. (2005) Educational Needs and Barriers for Refugee Students in the United States: A Review of the Literature. Review of Educational Research 75: 329-364. 
McBrien JL. (2011) The importance of context: Vietnamese, Somali, and Iranian refugee mothers discuss their resettled lives and involvement in their children's schools. Compare: A Journal of Comparative and International Education: 1.

Migration Policy Institute. (2014) Refugee Resettlement in the United States: Outcomes and Challenges. Washington, DC: Migration Policy Institute.

Moll LC, Amanti C, Neff D, et al. (1992) Fund of knowledge for teaching: Using a qualitative approach to connect homes and classrooms. Theory into Practice 31: 132-141.

Nykiel-Herbert B. (2010) Iraqi refugee students: From a collection of aliens to a community of learners. Multicultural Education 17: 2-14.

Prior MA and Niesz T. (2013) Refugee children's adaptation to American early childhood classrooms: A narrative inquiry. The Qualitative Report 18: 1-17.

Robinson WC. (1998) Terms of refuge : the Indochinese exodus and the international response, New York: Zed Books.

Rutter J. (2003) Supporting refugee children in 21st century Britain : a compendium of essential information, Stoke on Trent: Trentham Books.

Rutter J. (2006) Refugee children in the UK, Maidenhead, Berkshire: Open University Press.

Save the Children. (2013) Attacks on Education: The Impact of Conflict and Grave Violations on Children's Future. . London: Save the Children.

Schweitzer R, Melville F, Steel Z, et al. (2006) Trauma, post - migration living difficulties, and social support as predictors of psychological adjustment in resettled Sudanese refugees. Australian and New Zealand Journal of Psychiatry 40: 179-188.

Szente J, Hoot J and Taylor D. (2006) Responding to the special needs of refugee children: Practical ideas for teachers. Early Childhood Education Journal 34: 15-20.

Tao S. (2013) Why are teachers absent? Utilising the Capability Approach and Critical Realism to explain teacher performance in Tanzania. International Journal of Educational Development 33: 2-14.

Taylor S and Sidhu RK. (2012) Supporting refugee students in schools: what constitutes inclusive education? International Journal of Inclusive Education 16: 39-56.

UNESCO. (2015) EFA Global Monitoring Report: Education for All 2000-2015: Achievements and Challenges. Paris: UNESCO.

UNHCR. (2000) The State of the World's Refugees 2000: Fifty Years of Humanitarian Action. Geneva: UNHCR.

UNHCR. (2003) Education Field Guidelines. Geneva: UNHCR.

UNHCR. (2009) UNHCR Policy on Refugee Protection and Solutions in Urban Areas. Geneva: UNHCR.

UNHCR. (2010) Convention and Protocol Relating to the Status of Refugees. Geneva: UNHCR.

UNHCR. (2012) Education Strategy 2012-2016. Geneva: UNHCR.

UNHCR. (2013) Finding our Way: Education Strategy for Refugees in Chad 2013-2016. N'Djamena: UNHCR.

UNHCR. (2014a) Facts and Figures about Refugees. Available at: http://www.unhcr.org.uk/about-us/key-facts-and-figures.html

UNHCR. (2014b) Operations Plan: Egypt. Cairo: UNHCR.

UNHCR. (2014c) Resettlement Fact Sheet 2014. Available at: http://www.unhcr.org/pages/4a16b1676.html.

UNHCR. (2014d) Resettlement: A New Beginning in a Third Country. Available at: http://www.unhcr.org/pages/4a16b1676.html. 
UNHCR. (2014e) UNHCR Global Trends 2013: War's Human Cost. Geneva: UNHCR.

UNHCR. (2014f) UNHCR Policy on Alternatives to Camps. Geneva: UNHCR.

UNHCR. (2015a) 2015 UNHCR country operations profile - Pakistan. Available at: http://www.unhcr.org/cgi-bin/texis/vtx/page?page=49e487016\&submit=GO.

UNHCR. (2015b) UNHCR Refugee Resettlement Trends 2015. Geneva: UNHCR.

UNHCR and CARE. (2009) Filling the Gap? Informal Schools in Dadaab Refugee Camps: A Joint Study of UNHCR and CARE International Kenya. Dadaab Refugee Camp, Kenya: UNHCR and CARE.

UNICEF. (2008) Child protection from violence, exploitation and abuse: Children in Conflict and Emergencies. Available at: http://www.unicef.org/protection/index_armedconflict.html.

UNICEF. (2014) Press release: With 15 million children caught up in major conflicts, UNICEF declares 2014 a devastating year for children. Available at: http://www.unicef.org/media/media_78058.html.

United Nations. (2014) 2014 Syria Regional Response Plan: Strategic Overview. New York: United Nations.

United Nations. (2015) Children and Armed Conflict: Report of the Secretary-General. New York: United Nations General Assembly/Security Council.

Universalia Management Group. (2010) The Evolving Nature of UNRWA Schools. Universalia Management Group.

UNRWA. (2011) UNRWA Education Reform Strategy, 2011-2015. Amman: UNRWA.

Vavrus F and Bartlett L. (2013) Teaching in Tension: International Pedagogies, National Policies, and Teachers' Practices in Tanzania, Rotterdam: Sense Publishers.

Verdirame G and Harrell-Bond BE. (2005) Rights in exile : Janus-faced humanitariansism, New York: Berghahn Books.

Walker-Dalhouse D and Dalhouse AD. (2009) When Two Elephants Fight the Grass Suffers: Parents and Teachers Working Together to Support the Literacy Development of Sudanese Youth. Teaching And Teacher Education: An International Journal of Research And Studies 25: 328-335.

Winthrop R and Kirk J. (2011) Learning for a Bright Future: Schooling, Conflict, and Children's Well-Being. In: Mundy K and Dryden-Peterson S (eds) Educating Children in Conflict Zones: Research, Policy, and Practice for Systemic Change (A Tribute to Jackie Kirk). New York: Teachers College Press, 101-121.

World Conference on Education for All. (1990) World declaration on Education for All. Jomtien, Thailand: World Conference on Education for All. 